\title{
Management of Venous Priapism: Experience of Sylvanus Olympio University Hospital in Lomé (TOGO)
}

\author{
Komi Hola Sikpa*, Edoe Viyome Sewa, Efoe-Ga Amouzou, Gnimdou Botcho, Ananivi Sogan, Ta- \\ megnon Dossouvi, Essodina Padja, Boureima Ouedraogo, Essomindelou Leloua, \\ Messan Semefa Agbedey, Tchilabalo Matchonna Kpatcha, Kevin Kodjo Tengue
}

Université de Kara, Kara, Togo

Email: ^docjno@gmail.com

How to cite this paper: Sikpa, K.H., Sewa, E.V., Amouzou, E.G., Botcho, G., Sogan, A., Dossouvi, T., Padja, E., Ouedraogo, B., Leloua, E., Agbedey, M.S., Kpatcha, T.M. and Tengue, K.K. (2018) Management of Venous Priapism: Experience of Sylvanus Olympio University Hospital in Lomé (TOGO). Open Journal of Urology, 8, 289-296.

https://doi.org/10.4236/oju.2018.810033

Received: August 17, 2018

Accepted: October 26, 2018

Published: October 29, 2018

Copyright $\odot 2018$ by author and Scientific Research Publishing Inc. This work is licensed under the Creative Commons Attribution International License (CC BY 4.0).

http://creativecommons.org/licenses/by/4.0/

\begin{abstract}
Objective: To study the diagnostic, etiological, therapeutic and evolutionary aspects of patients received at the Sylvanus Olympio Hospital in Lomé for venous priapism. Patients and Methods: A cross sectional study, over 5 years (2012-2016), of 27 cases of low flow priapism treated at the Chu Sylvanus Olympio in Lomé. Results: The mean age of the patients was 28.14 years \pm 8.6. The average time of consultation was 106 hours (04 days 10 hours) \pm 208.02. In our study, 4 (14.81\%) patients consulted before the 6th hour and $20(74 \%)$ patients consulted after the 24th hour. The blood count required in all patients revealed a case of chronic myeloid leukemia. Hemoglobin electrophoresis resulted in $23(85.1 \%)$ cases of sickle cell disease. The management was medico-surgical. After an average follow-up of 11 months, erectile function was evaluated in 18 patients, and erectile dysfunction was noted in $10(55.5 \%)$ patients.
\end{abstract}

\section{Keywords}

Venous Priapism, Urgency, Drepanocytosis, Neuroleptics, Erectile Dysfunction

\section{Introduction}

Priapism is an abnormally prolonged erection, lasting more than 4 hours, painful and irreducible, occurring outside of any sexual stimulation, and not leading to ejaculation. In literature, the sickle cell disease is the most common cause surrounding 50\%, especially in black Africa, followed by drug etiology [1] [2] [3]. Whatever the cause, this is a real urological emergency, which suffers from 
the taboo nature of sexuality in our regions [4]. There is therefore a delay in the consultation, so as in the therapeutic management, which is harmful for erectile function [2]. The erectile dysfunction rate neighbors $45 \%-50 \%$ in literature [2] [5]. The lack of research on priapism in our country which does not have an adequate technical platform, the difficulties of its management, and the high frequency of erectile dysfunction that it causes in often young subjects, prompted us to describe the diagnostic, etiological, especially therapeutic and evolutionary peculiarities of the patients received at Sylvanus Olympio CHU of Lomé, for venous priapism.

\section{Patients and Methods}

This is a cross-sectional study, over 5 years, having as a framework, the Urology-Andrology department of Sylvanus Olympio CHU in Lomé, TOGO; the criteria for files selection were as follows: any file containing the following information has been retained; age, the elapsed time before the consultation, the notion of sickle cell disease or other hemoglobinopathy, drug taking or not, the existence of repeated episodes of prolonged spontaneously erections, the act of management, the evolution after care taking, and the quality of the erection. A total of 29 patients admitted for venous priapism during the study period. After processing, 27 files were selected.

After the clinical diagnosis of venous priapism, a hemogram and electrophoresis of hemoglobin were requested.

The therapeutic management of venous priapism was as follows: If the patient was admitted within the first six hours, the procedure was the use of "first-line treatments": exercise, ejaculation, ice packs, cold baths, cold water enemas, and oral intake of etilephrine; if the patient was admitted within 6 - 24 hours of the onset, a puncture of corpus cavernosum, associated with intracavernous injection of ephedrine, was performed every 10 minutes until a detumescence; if failure or recurrence, or if the patient arrived within $24-48 \mathrm{~h}$, a puncture of corpus cavernosum, and intracavernous injection of ephedrine, were carried out. In case of failure or reccurence, a caverno-spongy anastomosis was most often performed according to Al Ghorab method. It should be noted that, we do not have gasometry, to appreciate the intensity of the anoxic suffering, and to indicate the time of the surgery. We therefore prefer that of patients admitted after the $24^{\text {th }}$ hour, given the fact that we do not know whether there are criteria to severe hypoxia $\left(\mathrm{pH}<7.25, \mathrm{pO}_{2}<30 \mathrm{~mm} \mathrm{Hg}, \mathrm{pCO}_{2}>60 \mathrm{~mm} \mathrm{Hg}\right.$ ), not to take over the intracavernous injection of ephedrine, and make a surgical decision.

The different modalities of medical and/or surgical treatment have been analyzed. Post-management follow-up to assess erectile function has been done. Erectile function was assessed, based on anamnestic data collected during the control visits.

The analysis of the results was done with the software epi info 3.5.1. 


\section{Results}

The average age of the patients was 28.14 years $( \pm) 8.6$ with extremes of 18 and 55 years.

The predominant age group was 20 - 29 years old.

The average consultation time was 106 hours (04 days 10 hours) ( \pm ) 208.02 with extremes ranging from 4 hours to 1080 hours.

In our study, $4(14.81 \%)$ patients were consulted before the 6th hour and 20 (74\%) patients were consulted after the 24 th hour (Figure 1).

In their history, $5(18.5 \%)$ patients had prolonged spontaneous erections, and $6(22.2 \%)$ patients had previously experienced an episode of priapism.

The blood count required in all patients revealed a case of chronic myeloid leukemia.

Electrophoresis of hemoglobin, found 23 (85.1\%) cases of sickle cell disease: 9 (33.3\%) SS homozygous patients, 7 (25.9\%) SC patients, and 7 (25.9\%) AS patients.

In $1(3.7 \%)$ case, the patient took a neuroleptic notably chlorpromazine. No etiology was found in $2(7.4 \%)$ cases (Figure 2 ).

The treatment was medico-surgical. All patients received oral treatment with alpha stimulants (etilephrine). In 5 (18.5\%) patients, a corpus cavernous puncture was performed; in 19 (70.3\%) patients, cavernous body puncture and distal caverno-spongy anastomosis were performed according to Al Ghorab method afterwards, since they had a recurrence. In $3(11.1 \%)$ patients, only caverno-spongy anastomosis was used.

At an average follow-up of 11 months, erectile function could be assessed in 18 patients; erectile dysfunction was noted in 10 (55.5\%) patients. The IIEF-5 (International Index of Erectile Function 5) administered showed that: 4 (22.2\%) patients had severe erectile dysfunction and 6 (33.3\%) patients had moderate erectile dysfunction. The average time for consultation was 162.62 hours (approximately 6 days) ( \pm ) 257.82 in patients with erectile dysfunction, and 25.9 hours (approximately 1 day) ( \pm ) 24.89 in those who had normal erectile function

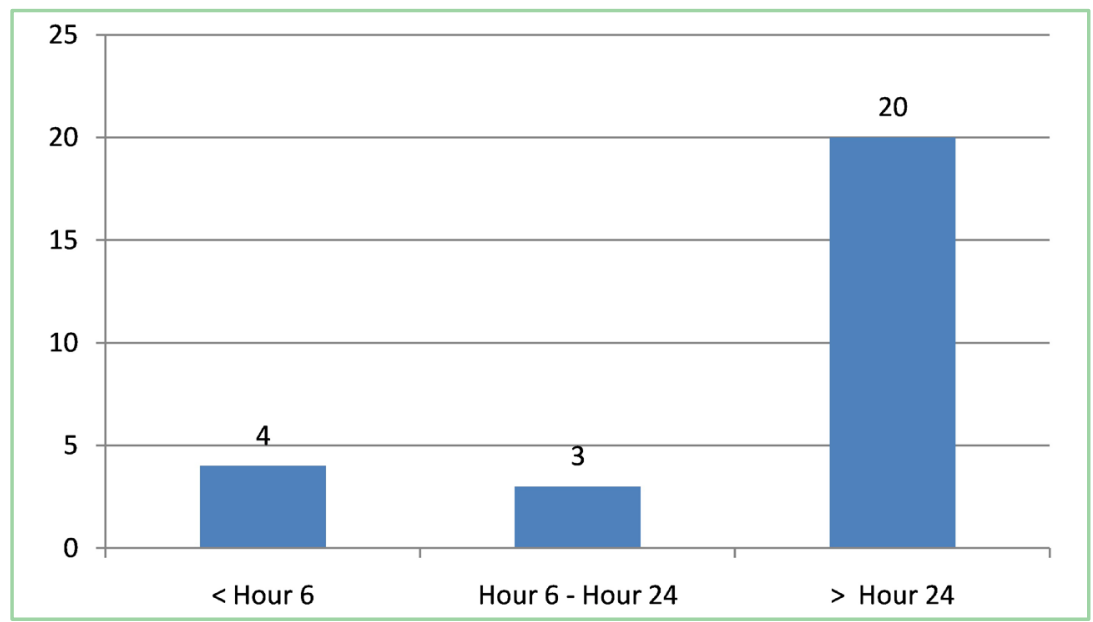

Figure 1. Distribution of patients by consultation time. 


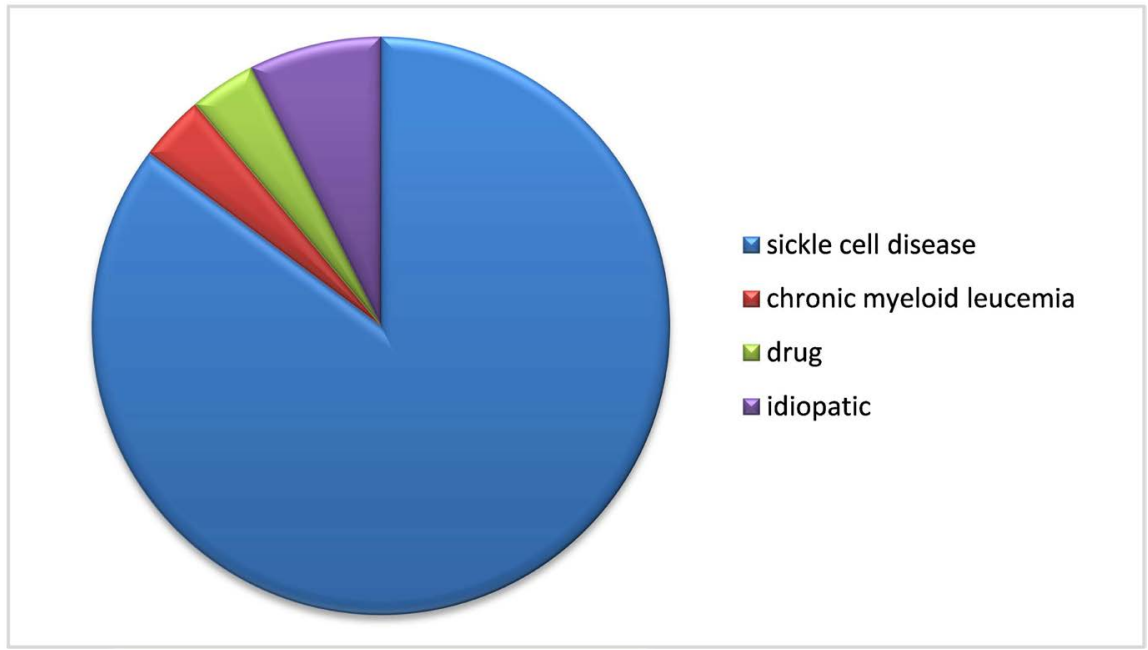

Figure 2. Distribution of patients according to etiology.

\section{Discussion}

Considered to be a trouble erection, venous priapism, in our study, touches a population with a sickle cell trait, with an average age of 28 years. There is a fairly high rate of erectile dysfunction as a complication. The prevalence of venous priapism was $23.6 \%$ in sickle cell patients during the early 2000s in our country [3], and $27.5 \%$ in sickle cell patients in the US [6]. The prevalence is $34 \%$ in sickle cell patients in Brazzaville [7]. These differences are due to the type of halotype, and to the geographical area [7]

It can occur at any age [8]. The average age of patients was 28.14 years \pm 8.6 with extremes of 18 and 55 years in our series. The predominant age group was 20 - 29 years old. Fall found an average age of 22.4 years with extremes of 3 and 68 years [2]. Only homozygous sickle-cell infants seem to be spared, due to the presence of fetal hemoglobin [9].

It is established that sickle cell disease is the main cause of venous priapism in our sub-Saharan regions [2] [7] [10]. The decrease in oxygen saturation of the arterial blood during sleep, and blood hyperviscosity, explain this association with sickle cell disease and venous priapism. In our study, $85.1 \%$ of patients had a sickle cell trait: $33.3 \%$ of SS homozygotes, $25.9 \%$ of SC heterozygotes, and $25.9 \%$ of AS heterozygotes.

The electrophoresis of hemoglobin in FALL's article found $46 \%$ of sickle cell disease, that is, $33.3 \%$ of homozygotes SS, and $12.8 \%$ of AS heterozygotes [2].

FALL found another hematologic cause: chronic myeloid leukemia with 1 case (3.2\%) [2]. We also found 1 case of chronic myeloid leukemia (3.7\%).

Drug causes are described in literature: neuroleptics, which alone account for $50 \%$ of drug priapism, are often incriminated, as are antidepressants, anticoagulants or antihypertensives, and also intracavernous injection of vasoactive drugs [11] [12]. The high affinity for alpha 1 adrenergic receptors for phenothiazines (neuroleptic) is the cause [11].

This makes some writers say that venous priapism occurs mainly on two 
grounds: the sickle cell ground and the psychiatric one. Kamel found in his study that the two frequently found grounds are sickle cell disease (28.5\%) and psychiatric illness (21.4\%) [5]. In our series, only one case of neuroleptic intake was found. The low rate of patients with venous priapism due to neuroleptics, could be explained by a not-yet-widespread prescription of this therapeutic class, in our country; indeed, the psychiatric patients who benefit from it do not always have the reflex to consult the specialist; simply because of ignorance, or lack of financial means, or because the entourage thinks that their psychiatric illness is due to witchcraft.

As for intracavernous injections of vasoactive drugs, they cause more prolonged erections (5\%), than true venous priapisms (1\%) [13].

The management of venous priapism will aim at getting a quick detumescence, to avoid recurrence, and especially to avoid side effects on erectile function. For this, the time factor becomes important. According to Droupy, smooth muscle histological lesions occur when priapism lasts 12 hours, and irreversible fibrotic lesions occur after 48 hours [13].

After detumescence, after treatment, all patients were put on cyproterone acetate (ANDROCUR $100 \mathrm{mg} /$ day) for a few days to prevent any recurrence immediately postoperatively and thus prevent erectile dysfunction sequellar.

The role of anti-androgens at moderate doses to prevent recurrence was mentioned by Dahm [14]; none of our patients experienced recurrence during the period of taking cyproterone acetate. Some had recurrence just after cyproterone acetate was discontinued. The anti-androgenic treatment has proved its effectiveness; but its main limitation lies in the fact that it is responsible for unacceptable side effects for young men: infertility and sexual dysfunction by hypogonadism [13].

In England, Kousournas [15] speaks of "Hormonal Therapies", which aims to suppress circulating testosterone in the blood. This has been made possible by the use of GnRH agonists or antagonists to control the pituitary gland; the use of Ketoconazole to reduce testosterone production; the use of antiandrogens (bicalutamide, flutamide) to block androgen receptors; the use of Finasteride to inhibit the transformation of testosterone into dihydrotestosterone. These methods have the same limit as cyproterone acetate except for Ketoconazole.

According to a randomized study, ketoconazole, in combination with prednisone, reduces postoperative recurrence, with no effect on fertility and sexual function. It is thus an alternative to antiandrogens, especially in young people [15].

Inhibitors of phosphodiesterase 5 (IPDE 5) have also been recommended to prevent recurrence. Experimental work has shown that abnormalities in the regulation of phosphodiesterase 5 activity may be involved in the occurrence of venous priapism [16].

It has therefore been proposed, despite the apparent illogicality of this approach, to prevent recurrent priapism, by using IPDE 5, usually prescribed on demand, to treat erectile dysfunction [17]. 
In a preliminary, uncontrolled test in 3 patients, inhibitors of phosphodiesterase 5 was taken at a distance from any sexual stimulation. In the long run, this therapeutic attitude has proved effective in preventing recurrent priapism. In parallel, it has been shown that continuous treatment with Inhibitors of phosphodiesterase 5 makes it possible to prevent the occurrence of priapism in an animal model of sickle cell disease by regulating the expression of phosphodiesterase 5 [18].

An improved scheme was proposed at a meeting of the American Urological Association in 2006: Sildenafil $25 \mathrm{mg}$ daily, in the morning, away from the waking period, usually with morning erections. Patients had to abstain from sexual stimulation within 8 hours of taking it. The duration of treatment was between 3 and 7 months, in non-sickle cell patients, and between 17 and 24 months in sickle cell patients [19].

Despite all these advances, we think with Chineqwundoh [20], that randomized tests must continue to find better treatments facilitating the management of venous priapism.

Erectile dysfunction is unfortunately common, when the management of venous priapism is not effective and early. Authors have found $55 \%$ of erectile dysfunction in their series [2]. Kamel thinks that apart from the delay in the management, another factor intervenes in the occurrence or not of the erectile dysfunction: age [5]. The retention rate of erectile power after priapism would be high in patients younger than 40 years, and this rate would be low in patients over 50 years of age [5] [21]. In our series, we found $61.1 \%$ of DE. One limitation of our study is the impossibility of evaluating erectile function in all our patients in the long term. Some of our patients disappeared after one month of follow-up

Unfortunately, it is an erectile dysfunction that does not often give way to the usual inhibitors of phosphodiesterase 5 (IPDE 5). Surgical placement of penile prostheses becomes the last resort. This is not easy because requiring drilling of the fibrous tissue at the corpus cavernosum, to provide space for the prosthesis. [22] [23].

\section{Conclusion}

Venous priapism presents as peculiarities, in Togo and in the sub-Saharan regions, the predominance of sickle cell etiology, and the consultation period too long. It will therefore be necessary to screen for sickle cell disease from an early age, and inform those concerned about the risks of priapism, and especially about the type of erectile dysfunction complications that may result, if management is not provided in the early hours. This erectile dysfunction being sequellar, by fibrosis of the cavernous bodies, it seriously mortgages the sexuality, and therefore the couples of the affected patients, who are mostly young.

\section{Acknowledgements}

Our sincere thanks to Mr DJAGRI and Mr SOA. 


\section{Conflicts of Interest}

The authors declare no conflicts of interest regarding the publication of this paper.

\section{References}

[1] Dekou, A., Ouegnin, G.A., Konan, P.G., Kouame, B. and Manzan, K. (2006) The Etiologies and Risk Factors of Priapism from a Series Collected in the Urology Department of the Cocody Teaching Hospital in Abidjan. Revue Internationale des Sciences Medicales d Abidjan, 8, 27-30.

[2] Fall, P.A., Diao, B., Ndoye, A.K., Ndiaye Diop, E., Sylla, C., Gueye, S.M. and Diagne, B.A. (2005) Priapism: Clinical and Etiological Specificities. Department of Urology-Andrology, A. Dantec and Hoggy Hospital, Dakar, Senegal. African Journal of Urology, 11, 186-190.

[3] Gbadoe, A.D., Dogba, A., Segbena, A.Y., Nyadanu, D.Y., et al. (2001) Priapism in Sickle Cell Anemia in Togo, Prevalence and Knowledge of This Complication. $\mathrm{He}-$ moglobin, 25, 355-361. https://doi.org/10.1081/HEM-100107871

[4] Slimen, M.H., Fakhfakh, H., Gassara, M., Kechaou, S., Bahloul, A. and Mhiri, M.N. (2008) Venous Priapism: Treatment and Functional Prognosis about 26 Cases. Urology Department, Habib Bourguiba University Hospital, Sfax, Tunisia. Andrology, 18, 264-273.

[5] Kamel, K., Mohamed, M., Abderrazek, B., Mohamed, C., Amine, D., Riadh, B.S., et al. (2016) Management of Low-Dose Priapism Seen Late: About 28 Cases. AJU, 22, 297-304.

[6] Mantadakis, E., Cavender, J.D., Rogers, Z.R., Ewalt, D.H. and Buchanan, G.R. (1999) Prevalence of Priapism in Children and Adolescents with Sickle Cell Anemia. Journal of Pediatric Hematology/ Oncology, 21, 518-522. https://doi.org/10.1097/00043426-199911000-00013

[7] Okoko, A.R., Odzebe, A.S.W., Middle, E., Ekouya Bowassa, G., Oko, A.P.G, MbikaCardorelle, A., et al. (2014) Priapism in Children and Homozygous Sickle Cell Patients in Brazzaville. Progrès en Urologie, 24, 57-61. https://doi.org/10.1016/j.purol.2013.04.021

[8] Majeed, S., Schor, J.A., Jacobson, S., Jagoda, A. and Mahadeo, R. (2000) Refractory Priapism of Unknown Etiology in a Pediatric Patient. Pediatric Emergency Care, 16, 347-351. https://doi.org/10.1097/00006565-200010000-00012

[9] Gentilini, M. (1993) Sickle Cell Tropical Medicine. Flammarion Edition, Paris, 513-522.

[10] Fall, B., Fall, P.A., Diao, B., Sow, Y., Dieng, E., Sarr, A., et al. (2010) Acute Priapism in Senegalese Sickle Cell Disease: Clinical, Therapeutic and Evaluation Aspects of Erectile Function. Andrology Urology Department, University Hospital Aristide Le Dantec Med. Medecine Tropicale, 70, 475-478.

[11] Marrag, I., Ben Soussia, R., Hajji, K., Zarrouk, L., Binous, Y. and Nasr, M. (2016) Chlorpromazine Induced Priapism: Two Cases Reports. African Journal of Urology, 22, 131-135. https://doi.org/10.1016/j.afju.2015.05.006

[12] Brichart, N., Delavierre, D., Peneau, M., Ibrahim, H. and Mallek, A. (2008) Priapism Associated with Antipsychotic Medications: A Series of Four Patients. Progrès en Urologie, 18, 669-673. https://doi.org/10.1016/j.purol.2008.04.010

[13] Droupy, S. and Giuliano, F. (2013) Priapisms. Progrès en Urologie, 23, 638-646. https://doi.org/10.1016/j.purol.2013.01.026 
[14] Dahm, P., Rao, D.S. and Donatucci, C.F. (2002) Antiandrogens in the Treatment of Priapism. Urology, 59, 138. https://doi.org/10.1016/S0090-4295(01)01492-3

[15] Kousournas, G., Muneer, A., Ralph, D. and Zacharakis, E. (2017) Contemporary Best Practice in the Evaluation and Management of Stuttering Priapism. Therapeutic Advances in Urology, 9, 227-238. https://doi.org/10.1177/1756287217717913

[16] Champion, H.C., Bivalacqua, T.J., Takimoto, E., Kass, D.A. and Burnett, A.L. (2005) Phosphodiesterase-5A Dysregulation in Penil Erectile Tissue Is a Mechanism of Priapism. Proceedings of the National Academy of Sciences of the United States of America, 102, 1661-1666. https://doi.org/10.1073/pnas.0407183102

[17] Burnett, A.L., Bivalacqua, T.J., Champion, H.C. and Musicki, B. (2006) Long-Term Oral Phosphodiesterase 5 Inhibitor Therapy Recurrent Alleviates Priapism. Urology, 67, 1043-1048. https://doi.org/10.1016/j.urology.2005.11.045

[18] Bivalacqua, T.J., Champion, H.C., Mason, W. and Burnett, A.L. (2006) Long-Term Phosphodiesterase Type 5 Inhibitor Therapy Reduces Priapic Activity in Transgenic Sickle Cell Mice. The Journal of Urology, 175, 387. https://doi.org/10.1016/S0022-5347(18)33427-X

[19] Burnett, A.L., Bivalacqua, T.J., Champion, H.C. and Musicki, B. (2006) Long-Term Oral Phosphodiesterase-5 Inhibitor Therapy Recurrent Alleviates Priapism. 100th Meeting American Urological Association, Atlanta, 21-25 May 2006. Urology, 67, 1043-1048.

[20] Chinagwundoh, F.I., Smith, S. and Anie, K.A. (2017) Treatments for Priapism in Boys and Men with Sickle Disease. Cochrane Database of Systematic Reviews, 9 , CD004198.

[21] Khoriaty, A.V. and Schick, E. (1980) The Surgery of Priapism. The Journal of Urology, 86, 283-291.

[22] Bondil, P. (1986) Iatrogenic Priapism by Intracavernous Injection of Vasoactive Drugs in the Treatment of Impotence. Presse Medicale, 15, 655.

[23] Gerstenbluth, R.E., Kick, P.S., Srodes, A.D. and Seftel, A.D. (2003) Priapism Secondary to Hypertriglyceridemia. The Journal of Urology, 169, 1088.

https://doi.org/10.1097/01.ju.0000052645.28725.af 